\title{
Obesity Status of University Employees and Associated Factors: Turkey-2015
}

\author{
Bir Üniversite Çalışanlarının Obezite Durumu ve İlişkili Etmenler: Türkiye-2015
}

\author{
(1) Gülcan Demir Özdenk ${ }^{1}$, (ㄴ) Lütfiye Hilal Özcebe 2 \\ 1Sinop University Vocational School of Health Services, Department of Medical Services and Techniques, Sinop, Turkey \\ ${ }^{2}$ Hacettepe University Faculty of Medicine, Department of Public Health, Ankara, Turkey
}

\begin{abstract}
Introduction: Obesity is a growing public health concern with increasing prevalence in the world. It is aimed to investigate the relationship between socio-demographic features, dietary habits, physical activity level and body mass index (BMI) of the officers and contracted staff between the ages of 1864 working in administrative units of a university and some factors affecting these relationships.

Methods: The population of this cross-sectional study consists of officers and contracted staff working at a university campus. The data were evaluated by using SPSS 20.0 program. Descriptive statistics, chi-square test and three different binary logistic regressions were conducted in the study.

Results: The mean age of the employees was $36.4 \pm 8.23$ years and $67.4 \%$ of the participants were male. Half of the participants had bad dietary habits, $15.8 \%$ of the participants were physically "active" and $68.2 \%$ were overweight and obese. Being male and the importance given to health (good and above) were found to be protective factors against the bad dietary habits. Low educational level (1.88) and being married (2.32) were the risk factors for bad dietary habits. Males (2.78), married participants (1.94), participants with good and above importance given to health (1.62) and participants working as a contracted staff (2.68) were found to be physically more active. Being male (2.16), having children (2.32) and being physically active (1.78) were found to be risk factors for overweight and obesity.

Conclusion: It was found that there were differences in nutrition, physical activity and obesity among university staff with different social structures. Awareness of BMI values, healthy nutrition and physical activity levels should be increased in the intervention programs aimed at changing the lifestyle of individuals working in different statuses in the society.
\end{abstract}

Keywords: Adult, body mass index, dietary habits, obesity, physical activity

\section{ÖZ}

Amaç: Dünyada giderek artış gösteren obezite büyüyen bir halk sağlığı endișesidir. Bir üniversitede, 18-64 yaș arasında idari teșkilatta görev yapan memurların ve sözleșmeli olarak çalışan personelin sosyo-demografik özellikleri, beslenme alıșkanlıkları, fiziksel aktivite düzeyi ve vücut kitle indeksi (VKi) ile aralarındaki ilişkiyi etkileyen bazı faktörlerin incelenmesi amaçlanmıştır.

Yöntemler: Kesitsel araştırmanın evrenini, bir üniversiteye bağlı yerleșkelerde memur ve sözleșmeli personel olarak çalışan katılımcılar oluşturmaktadır. Verilerin değerlendirilmesi SPSS 20.0 programı kullanılarak yapılmıștır. Çalışmada tanımlayıcı istatistikler, ki-kare testi ve üç farklı ikili lojistik yapıımıștır.

Bulgular: Çalışanların yaş ortalaması $36,4 \pm 8,23$ yıl olup $\% 67,4$ 'ü erkektir. Katılımcıların yarısı kötü beslenme alışkanlıklarına sahiptir ve katılımcıların \%15,8'i fiziksel olarak "aktif" ve \%68,2'si kilolu ve șișman olarak bulunmuștur. Erkek olmak ve sağlığa verilen önem (iyi ve üzeri) kötü beslenme alışkanlıklarına karşı koruyucu faktör olarak bulunmuștur. Düşük eğitim düzeyi $(1,88)$ ve evli olma $(2,32)$ durumu kötü beslenme alışkanlıkları için risk faktörleridir. Erkekler $(2,78)$, evliler (1,94), sağlığa verilen önem (iyi ve üzeri-1,62) ve sözleșmeli ișçi $(2,68)$ olarak çalışanlar fiziksel olarak daha aktif olduğu bulunmuștur. Erkek cinsiyet $(2,16)$, çocuk sahibi olma $(2,32)$ ve fiziksel aktif olma $(1,78)$ durumu așırı kiloluluk ve obezite için risk faktörleri olarak bulunmuştur.

Sonuç: Aynı üniversitede çalışan farklı sosyal yapıya sahip olan kesimler arasında beslenme, fiziksel aktivite ve șișmanlık düzeylerinin farklılıkları olduğu bulunmuștur. Toplum içindeki farklı statülerde çalışan bireylerin yaşam tarzının değiştirilmesine yönelik müdahale programlarında, VKi değerleri konusunda bilinçlendirilmesi, sağıklı beslenme ve fiziksel aktivite düzeylerinin artırılması gerekmektedir.

Anahtar Kelimeler: Yetișkin, beden kitle indeksi, beslenme alıșkanlıkları, șișmanlık, fiziksel aktivite

Address for Correspondence/Yazıșma Adresi: Gülcan Demir Özdenk, Sinop University Vocational School of Health Services, Department of Medical Services and Techniques, Sinop, Turkey

Phone: +90 5306969901 E-mail: gdozdenk@ahievran.edu.tr ORCID ID: orcid.org/0000-0003-4639-399X

Cite this article as/Atıf:Demir Özdenk G, Özcebe LH. Obesity Status of University Employees and Associated Factors: Turkey-2015. İstanbul Med J 2019; 20(2): 137-43.

(c) Copyright 2019 by the Istanbul Training and Research Hospital/Istanbul Medical Journal published by Galenos Publishing House.

(C) Telif Hakkı 2019 istanbul Eğitim ve Araștırma Hastanesi/Istanbul Tıp Dergisi, Galenos Yayınevi tarafından basılmıștır.

Received/Geliș Tarihi: 07.06.2018 Accepted/Kabul Tarihi: 07.11.2018 


\section{Introduction}

In recent years, being overweight and obesity have been emphasized as global public health problems with dramatic increase, Unhealthy nutrition and physical inactivity are among the leading causes of obesity. One of the main causes of obesity is the energy imbalance between calorie intake from foods and calories consumed. Globally, the food choice of people is becoming more unhealthy and there is an increase in physical inactivity due to increased consumption of high-fat foods, widespread consumption of fast-food products, rapid urbanization, changes in transport and working styles depending on the developments in technological areas, increase in the sedentary lifestyle arisen from the increase in the level of welfare, and lack of supportive environments. These changes provide a basis for various health problems, especially obesity (1).

According to the World Health Organization (WHO), obesity is a health problem defined as "abnormal or excessive fat accumulation that may impair health" (1). Overweight and obesity are among the important risk factors for most of the Non-Communicable Diseases (NCD) such as diabetes, cardiovascular diseases and cancer (2). According to the report of Turkey Nutrition and Health Survey (TNHS) in 2010, it was stated that prevalence of mild obesity among adults in Turkey was 34.6\% and prevalence rate of obesity was $30.3 \%$ (3).

WHO states that physical inactivity is the fourth most important cause for mortality at the global level and that it has caused the death of approximately 3.2 million people worldwide. According to WHO, one out of every four adults are not active enough and this situation is similar in Turkey (4). In the TNHS report, it was stated that the percentage of people who did not exercise was $71.9 \%$. There are approximately seven out of every ten men and eight out of every ten women who do not exercise throughout the country (3). Several studies have found a positive correlation between regular physical activity and prevention, treatment and management of NCD. In addition, the role of regular physical activity in improving health and preventing diseases has been inclusively described (5,6). Regular physical activity facilitates body weight management by providing energy expenditure (2). It is possible to reduce the incidence of NCD by modifying and managing behavioral risk factors that cause obesity and physical inactivity $(7,8)$. In physically active adults, the risk of premature death can be reduced by $20-30 \%$, and the risk of NCD development can be reduced by up to $50 \%(9,10)$.

In Turkey, as in the world, an unhealthy diet and physical inactivity are among the preventable, serious risk factors for obesity and associated NCDs (1). Based on the fact that working style is an important factor in the development of obesity, it is necessary to determine the dietary habits, physical activity levels and body mass index (BMI) values of the employees working at desk jobs and contracted staff, and to provide evidences based on the situation determination researches for these interventions. Conducting studies on obesity status of people from different segments of society and examining these studies especially in terms of the relationship between dietary habits and physical activity level are important for the evaluation of the obesity prevention and control program.

\section{Methods}

The necessary institutional permission was obtained from the Ahi Evran University Ethics Committee rectorate and ethical approval (number: 78968926-051/1076-5326) was received from the university ethics committee within the scope of ethical conduct in human research number 20696. Employees have been informed about the content and purpose of the research and it was stated that participation in the survey was based on voluntariness, and verbal consent of the employees were taken.

This cross-sectional study was conducted with a total of 554 employees working at the administrative units of a university as officer and contracted staff. The working statuses used in the study were defined as "officer is a person who performs fundamental and continuous public services by the state" and contracted staff was defined as "a person working in temporary jobs in the required areas in case of a vacant position" (11).

The data of the study were collected by visiting 9 different campuses in November-December 2015. The sample was not selected. The university employee or contracted personnel between 18-64 years of age who were at least primary school graduates were tried to be reached and the rate of participation was $85.9 \%$. Some of the employees did not participate in the study due to reasons such as being on leave, attending meetings, being on maternity leave and working hard due to supervision. The data obtained from the participants were collected by observation-based survey technique.

The dependent variables of the study were the dietary habits questionnaire scoring form, the International Physical Activity Questionnaire-Short Form (IPAQ-Short Form) and WHO adult BMI classification. The independent variables of the study were age, gender, educational status, employment type, marital status, parental status, family type, dietitian application status and level of importance given to health. Physical activity level and dietary habits were also evaluated as independent variables.

Dietary Habits Questionnaire: A questionnaire on dietary habits scoring developed by Arslan et al. (12) was used in the evaluation of dietary habits. When the person gets a healthy, adequate and balanced nutrition, she/he gets full score from the questionnaire. The total number of questions in the questionnaire is nine and the maximum score is 62 . Dietary habits were evaluated as poor ( $<35$ points), moderate $(35-48$ points) and good ( $>48$ points) in accordance with the scores obtained from the questionnaire (12).

IPAQ-Short Form: The validity and reliability of the IPAQ Short Form has been validated in Turkish. The questionnaire used in this study includes questions about the types (walking, moderate-intensity and vigorous-intensity physical activities and sitting duration), duration and frequency of physical activity performed at least 10 minutes in the "last seven days". In order to determine the level of physical activity, the total score is calculated by converting the data of walking, moderate-intensity and vigorous-intensity physical activities into metabolic equivalent of task (MET) values. According to the total score obtained, the physical activity levels of the participants were determined and classified as METmin/week. Physical activity levels were evaluated in three categories: 
inactive (<600 MET-min/week), minimally active (600-3000 MET-min/ week) and active (>3000 MET-min/week (13).

Anthropometric Measurements: Body weights and statuses of the employees participated in the study were measured by visiting the relevant department in the first hours of morning shift. The anthropometric measurements were made in the Frankfort plane through the SECA 813 electronic scale (Seca, Hamburg, Germany) and the SECA 213 stadiometer (Seca, Hamburg, Germany), with their underwear, by taking off their clothes and shoes. All measurements were made by the same researcher in an appropriate room, preferably with an empty stomach. The BMIs of the employees were calculated from the equation [body weight/stature $\left.\left(\mathrm{m}^{2}\right)\right](14)$. BMI results were evaluated according to the WHO classification of adult BMI. Participants were classified as underweight $(<18.5)$, normal (18.5-24.9), overweight (25.0-29.9) and obese (230.0) according to the values obtained from the BMI equation (15).

\section{Statistical Analysis}

Statistical analyzes were assessed by using the SPSS 20 (SPSS 20.0 for Windows, Chicago, III. USA) package program. Descriptive statistics (percent distribution, mean and standard deviation, median, distribution interval) were used in the summary of the data and chi-square test was used for comparing the groups. For multivariate analysis, the possible factors identified with univariate analyses were further entered into

\begin{tabular}{|c|c|c|}
\hline & \multicolumn{2}{|l|}{ Total } \\
\hline & Number & Percentage \\
\hline \multicolumn{3}{|l|}{ Gender ( $n=476)$} \\
\hline Male & 321 & 67.4 \\
\hline Female & 155 & 32.6 \\
\hline \multicolumn{3}{|l|}{ Education Status ( $n=476)$} \\
\hline Primary school and below & 67 & 14.1 \\
\hline High school & 127 & 26.7 \\
\hline Associate degree and above & 282 & 59.2 \\
\hline \multicolumn{3}{|l|}{ Type of employment ( $n=476)$} \\
\hline Officer & 301 & 63.2 \\
\hline Contracted staff & 175 & 36.8 \\
\hline \multicolumn{3}{|l|}{ Marital status $(n=476)$} \\
\hline Married & 370 & 77.7 \\
\hline Single & 106 & 22.3 \\
\hline \multicolumn{3}{|l|}{ Parental statıs * $(n=475)$} \\
\hline Yes & 337 & 70.8 \\
\hline No & 139 & 29.2 \\
\hline \multicolumn{3}{|c|}{ Level of importance given to health* $(n=468)$} \\
\hline Very poor & 11 & 2.3 \\
\hline Poor & 25 & 5.3 \\
\hline Average & 172 & 36.8 \\
\hline Good & 216 & 46.2 \\
\hline Excellent & 44 & 9.4 \\
\hline
\end{tabular}

the logistic regression (Forward Stepwise-Likelihood Ratio) analysis to determine independent predictors of dependent variables. HosmerLemeshow goodness of fit statistics were used to assess model fit. Odds ratio (Odds Ratio) and 95\% confidence interval (Cl) were calculated. A 5\% type 1 error level was used to infer statistical significance.

In the further analysis, dependent variables were categorized and analyzed as [poor (reference), moderate and good] for dietary habits, [inactive (reference), minimal active and active] for physical activity level and BMI [normal and below (reference), overweight and above] for BMI values.

\section{Results}

The mean age of the 471 university employees participated in the study was $36.4 \pm 8.23$ years, median age was 35 , and the youngest and oldest participants were 20 and 62 years old (not given in the Table).

Sixty-seven point four percent of the employees were male, 59.2\% were graduated from "associate degree and above" and 63.2\% were employed as officers. Seventy-seven point seven percent of the employees stated that they were married, $70.8 \%$ stated that they had children and $55.6 \%$ stated that they gave importance to their health at the level of "good and above" (Table 1).

Forty-eight point five percent of the employees had moderate and good dietary habits. Males had better dietary habits than females $(p=0.017)$ (Table 2).

The physical activity level of $58.9 \%$ of the employees was found to be "minimally active and above". Physical activity level of males (65.1\%) was higher than the females $(45.8 \%)(p<0.001)$. The percentage of physical activity of employees graduated from "high school and below" was higher than the employees graduated from "associate degree and above" ( $p=0.017)$. The physical activity level of $55.9 \%$ of married employees and $68.9 \%$ of single employees was "minimally active and above" $(p=0.017)$. Seventy-two percent of contracted staff and $51.2 \%$ of officers were physically "active" $(p<0.001)$. Sixty-three point eight percent of the employees who declared the level of importance given to health as "good and above" and 52.9\% of the employees who declared the level as "poor and below" were found to be physically active $(p=0.017)$ (Table 2).

Sixty-eight point two percent of the employees were overweight and obese, and males (74.2\%) were more overweight and obese than the females $(55.8 \%)(p<0.001)$. The ratio of "overweight and obese" was higher in the age group "40 years and older" than other age groups $(p<0.001)$. Seventy-three point five percent of married individuals and $49.0 \%$ of single individuals were "overweight and obese" $(p<0.001)$. The percentage of being "overweight" and "obese" was higher in the employees who had children $(\boldsymbol{p}<0.001)$ (Table 2).

Odds Ratio and 95\% Cl were calculated through logistic regression analysis by correcting the factors such as gender, marital status and level of importance given to health through dietary habits. The constant coefficient of the model for the dietary habits was found to be -0.523 . Males have 1.68 (1.13-2.50) times better dietary habits than females $(p=0.010)$. Single individuals have $1.61(1.03-2.51)$ times better dietary habits than the married individuals $(p=0.033)$ (Table 3 ). 


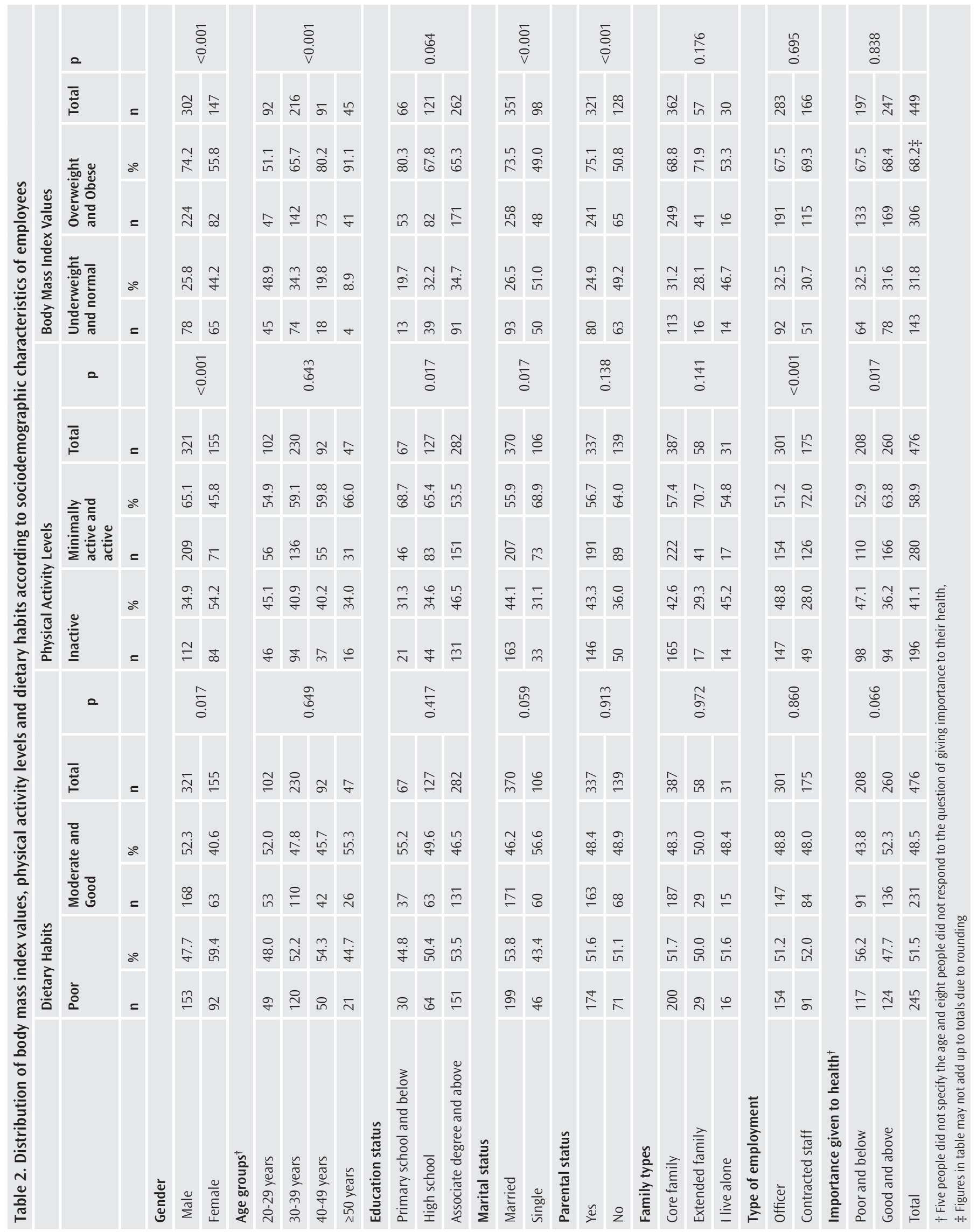


Table 3. Relationship between variables with dietary habits, physical activity level and body mass index values

\begin{tabular}{|c|c|c|c|c|c|c|c|}
\hline & & Dietary Habit & & Physical Act & & Body Mass Inc & \\
\hline & & OR (\%95 Cl) & p & OR (\%95 Cl) & $p$ & & \\
\hline Age & & & & & & $1.636(1.214-2.205)$ & 0.001 \\
\hline Gender & Female & Reference & & Reference & & Reference & 0.002 \\
\hline & Male & $1.688(1.136-2.508)$ & 0.010 & $2.728(1.779-4.184)$ & $<0.001$ & $2.045(1.307-3.202)$ & \\
\hline Marital Status & Married & Reference & & Reference & & & \\
\hline & Single & $1.618(1.039-2.519)$ & & $2.021(1.231-3.318)$ & 0.005 & & \\
\hline Parental status & Yes & - & & - & & $2.048(1.235-3.398)$ & 0.006 \\
\hline & No & - & & - & & Reference & \\
\hline Importance given & Poor and below & - & & Reference & & - & - \\
\hline & Good and above & - & & $1.596(1.077-2.364)$ & & - & - \\
\hline Type of & Officer & - & & Reference & & - & - \\
\hline employment & Contracted staff & - & & $2.984(1.937-4.599)$ & $<0.001$ & - & - \\
\hline Level of physical & Inactive & - & - & - & - & Reference & 0.015 \\
\hline & $\begin{array}{l}\text { Minimally active } \\
\text { and active }\end{array}$ & - & - & - & - & $1.724(1.113-2.670)$ & \\
\hline
\end{tabular}

Odds Ratio and 95\% Cl were calculated through logistic regression analysis by correcting the factors such as gender, education status, marital status, parental status and family types through physical activity levels. The constant coefficient of the model for the level of physical activity was found to be -1.081. Males were 2.72 (1.77-4.18) times, single individuals were 2.02 (1.23-3.31) times, those who gave importance to their health at the level "good and above" were 1.59 (1.07-2.36) times and contracted staff was 2.98 (1.93-4.59) times more physically active than the others $(p<0.001, p=0.005, p=0.020, p<0.001)$ (Table 3$)$.

Odds Ratio and $95 \% \mathrm{Cl}$ were calculated through logistic regression analysis by correcting the factors such as age, gender, education status, family types, marital status, parental status and level of physical activity through BMI. The constant coefficient of the model for BMI was found to be -1.536. The advancing age increased the risk of being overweight and obese by $1.63(1.21-2.20)$ times ( $p=0.001)$. When the effect of gender on body mass index was examined, significant results were obtained. The risk of being "overweight and obese" was 2.04 (1.30-3.20) times higher in males and 2.04 (1.23-3.39) times higher in those who had children $(p=0.002, p=0.006)$. Individuals with "minimally active and active" physical activity level were $1.72(1.11-2.67)$ times more likely to be "overweight and obese" than those who are inactive $(p=0.015)$ (Table 3$)$.

\section{Discussion}

Unhealthy dietary habits and inadequate physical activity cause obesity problems. In this study, it was aimed to determine dietary habits, physical activity levels and obesity status of employees working in a university and some socio-demographic characteristics affecting them. Nutrition is one of the major determinants of health and many important NCDs can be prevented or delayed. Almost half of the employees (48.5\%) had better dietary habits, which means about 5 out of 10 people ate healthy. This shows that approximately half of the surveyed group was fed healthy.

In this study, it was found that men's dietary habits were 1.68 times better. Unlike these findings, different studies have shown that women's dietary habits are better than men $(16,17)$. The reason why our results are different is that male participants are outnumbered in administrative staff and that the working status has revealed more regular nutritional behaviors.

Single individuals have 1.61 times better dietary habits. In this study, it can be said that men have regular nutritional habits because they mostly work in office services and professional occupational groups. In this study, employees working at different campuses of the university were contacted. Healthy nutrition environment may not be provided in every campus. The characteristics of the nutritional environment are likely to affect the sociodemographic characteristics of the people (18). For this reason, it is also an important and controversial issue that it is necessary to investigate the obstacles for adequate and balanced nutrition of people, as well as their knowledge, and to provide solutions for these, and to establish nutrition friendly circles.

In the TNHS-2010 report, the percentage of individuals aged 12 years and over who exercise 1-2 times a week in the last 7 days is reported to be $9.7 \%$ in total (3). In this study, physical activity level of $9.3 \%$ of the employees working at desk jobs was found to be "active". In studies conducted with people working at desk jobs in Turkey, the percentage of physically "active" participants is 5.8\%-25.9\% (19-21). In this study, it was seen that the officers working at desk jobs were living more sedentarily than the other groups.

In the study, men were physically 2.72 times more active than women. A systematic review of the different studies conducted in our country 
$(14,22-24)$ and in other countries suggests that men have higher level of physical activity than women. When we compared our study with the other studies in which the level of physical activity of men was higher than that of women, the study was consistent with the literature.

Single employees were 2.02 times more physically active. Trost et al. (23) have stated in the systematic study that there are studies that show a positive relationship between marital status and physical activity and that there are also conflicting studies (23). Similar results have been found in the study of the Bulut (22) and Deniz (25). In our study, the reason why physical activity levels of single individuals were higher was that married individuals spend their free time with their families and they are older.

Individuals who give importance to their health at the level of "good" and "above" were 1.59 times more physically active than those with "poor and below" level. Trost et al. (23) reported that there was a positive correlation between perceived health status and physical activity, and that it was repeated in all study findings . Likewise, in the study of Yetim (24), it was stated that the average IPAQ scores was highest among those evaluating general health status as very good. Unlike the findings of this study, Bulut (22) stated that there was no significant difference in the physical activity levels of those who assessed their health status through their statements as "very good/good" "not bad" or "bad/very bad" (22). In order to obtain a better health level, individuals need to have a healthy life style. It is expected that those who give importance to their health should avoid the risky behaviors and apply healthy living principles that will protect and improve their health. It is essential to quit using tobacco and tobacco products, to avoid excessive alcohol consumption, to get healthy nutrition and to do regular physical activities for living a healthy life.

Contracted staff was 2.98 times more physically active than officers. Similarly, in the study of Bulut (22), it was stated that the level of physical activity of private company personnel was higher than the administrative personnel and it was found to be statistically significant (22). Contracted personnel, who has high levels of activity, are working in jobs that require to exert more power and energy and that sometimes require working overtime (security, cafeterias, cleaning etc.).

In parallel with the increase in BMI values in the world, it is observed that the percentage of obesity is also increasing. In TNHS-2010 report, it was stated that the prevalence of mild obesity was $34.6 \%$ and the prevalence of obesity was $30.3 \%$ in Turkey (3). In TURDEP-II study, the prevalence overweight and obesity in Turkey was reported to be $37.0 \%$ and $36.0 \%$, respectively (26). In this study, the percentage of overweight was $47.4 \%$ and percentage of obesity was $20.7 \%$. Various studies conducted in Turkey have shown different results in terms of the prevalence of overweight (25.0\%-47.4\%) and obesity (19.4\%-32.0\%) (27-29). The results of this study have similar values. The results suggest that obesity is a primary health problem in this group.

The increase in age also increases the risk of being overweight and obese by 1.63 times. According to the Turkey Nutrition and Health Survey (TNHS) 2010 report, which supports the finding of this study, it is stated that BMI increases with age and the percentage of being overweight and obese in the 51-64 age group is higher than other age groups (3).
In TNHS-2010 report, the prevalence of obesity (BMI $\left.\geq 30 \mathrm{~kg} / \mathrm{m}^{2}\right)$ in male individuals was $20.5 \%$, while it was $41.0 \%$ in female individuals and prevalence of overweight was higher in male individuals (M: $39.1 \%$, F: 29.7\%) (3). According to the findings of TURDEP II study, BMI values were higher in women compared to the mean of both genders (26). When the effect of gender on BMI was examined, significant results were obtained, and it was found that the risk of being overweight and obese for men was 2.04 times higher than women. According to our research, the prevalence of obesity in women was clearly lower than that of men, which might be because the age groups of the employees participating in the study are lower than the compared studies.

The risk of being "overweight and obese" in individuals with children was 2.04 higher than the others. According to the BMI evaluation in the study by Çayır et al. (30), the percentage of obesity also increases as the number of children increases. In the study of Erem et al. (28), it was stated that there was a linear relationship between the number of parity and the prevalence of obesity and BMI in women and that the prevalence of obesity and BMI level increases as the number of parity increases. The results are consistent with the results obtained in this study. In other words, the main demographic factors remain at the forefront in obesity. As the number of children increases with age, the age factor should not be ignored in these differentiations.

Population-based cross-sectional studies conducted to determine the relationship between physical activity and weight gain show an inverse relationship between physical activity level and weight gain, body fat increase, overweight or obesity prevalence (31). In our study, it was determined that the risk of being overweight and obese increased in individuals who are minimally active and active (1.72 times). In some studies, an inverse relationship between physical activity and BMI was reported (28). With these findings, which are inconsistent with the literature, it can be considered that individuals are trying to be physically active because of obesity.

Since participants are a group of people working as administrative and contracted staff at a university, they represent only a specific sub-group of the society, not the entire society. It should also be assessed in the interpretation of the findings that the dietary habits and physical activity level of the participants were determined by their own statements. The most important limitation of this study was that environmental conditions were not evaluated in terms of healthy nutrition and physical activity.

\section{Conclusion}

All these results suggest that interventions are needed to increase physical activity to prevent obesity. Interventions are needed to enable people to perform physical activities appropriate to their working and living conditions.

In conclusion, prominence of gender, which is a sociodemographic characteristic, in the formation of nutritional habits, physical activity and obesity is noteworthy. Marital status, the level of giving importance to health and employment type are important in eating habits and physical activity behaviors. The increase in age, having a child and the level of physical activity are important variables in obesity. All these 
results suggest that interventions are needed to increase physical activity to prevent obesity. Interventions are needed to enable people to perform physical activities appropriate to their working and living conditions. In this respect, age and gender-specific nutrition, obesity and physical activity policies that address all employees and programs on promoting and improving health are required to be developed. It is also thought that it is necessary to learn the social and cultural lifestyle as well as the environmental conditions that may affect healthy nutrition and physical activity.

Ethics Committee Approval: The necessary institutional permission was obtained from the Ahi Evran University rectorate and ethical approval (number: 78968926-051/1076-5326).

Informed Consent: Verbal consent of the employees were taken.

Peer-review: Externally and internally peer-reviewed.

Author Contributions: Concept - G.D.Ö., L.H.Ö.; Design - G.D.Ö., L.H.Ö.; Supervision - G.D.Ö.; Resources - G.D.Ö.; Data Collection and/or Processing - G.D.Ö., L.H.Ö.; Analysis and/or Interpretation - G.D.Ö., L.H.Ö.; Literature Search - G.D.Ö.; Writing Manuscript - G.D.Ö., L.H.Ö.; Critical Review - G.D.Ö., L.H.Ö.

Conflict of Interest: No conflict of interest was declared by the authors. Financial Disclosure: The authors declared that this study received no financial support.

\section{References}

1. WHO. Obesity and overweight (serial online). 2018 Mar (cited 2018 March 4). Available from: URL: http://www.who.int/mediacentre/factsheets/ fs311/en/

2. Bowman SA. Dietary and lifestyle practices of normal weight and overweight US adults. Body Mass Index: New Research 2005: 118-33.

3. Bakanlı̆̆ı TS. Türkiye beslenme ve sağlık araștırması 2010: Beslenme durumu ve alışkanlıklarının değerlendirilmesi sonuç raporu. Ankara, Sağık Bakanlığı Sağlık Araștırmaları Genel Müdürlüğü. 2014.

4. WHO. Physical activity (serial online). 2017 Apr (cited 2017 April 27). Available from: URL:http://www.who.int/mediacentre/factsheets/fs385/en/

5. Baptista F, Kathleen FJ. Physical activity in growth and development. İn: Ainsworth BE, Macera CA, editors. Physical activity and public health practice. Boca Raton: CRC Press; 2012.p.114-18.

6. Bell JA, Hamer M, van Hees VT, Singh-Manoux A, Kivimäki M, Sabia S. Healthy obesity and objective physical activity. Am J Clin Nutr 2015; 102: 268-75.

7. Bueno-de-Mesquita HB. Noncommunicable diseases of major public health interest and prevention. Asia Pac J Public Health 2015; 27: 110-5.

8. Riley L, Guthold R, Cowan M, Savin S, Bhatti L, Armstrong T, et al. The World Health Organization STEP wise approach to noncommunicable disease riskfactor surveillance: methods, challenges, and opportunities. Am J Public Health 2016; 106: 74-8.

9. Murphy R, Dugdill L, Crone D. Physical activity and health promotion: evidencebased approaches to practice. United States: John Wiley \& Sons; 2009.

10. Loitz CC, Potter RJ, Walker JL, McLeod NC, Johnston NJ. The effectiveness of workplace interventions to increase physical activity and decrease sedentary behaviour in adults: protocol for a systematic review. Syst Rev 2015; 4: 178 .

11. Kanunu SHT, Tazminat SP. Devlet memurları kanunu ve tababet ve șuabatı sanatlarının tarzı icrasına dair kanun ile sağıı bakanlığının teșkilat ve görevleri hakkında kanun hükmünde kararnamede değişiklik yapılmasına dair kanun: Kanun; 2016
12. Arslan P, Karaağaoğlu N, Duyar I, Güleç E. Yükseköğrenim gençlerinin beslenme alıșkanlıklarının puanlandırma yöntemi ile değerlendirilmesi. Besl Diyet Derg 1994; 22: 195-208.

13. Bozkuş T, Türkmen M, Kul M, Özkan A, Öz Ü, Cengiz C. Beden eğitimi ve spor yüksekokulu'nda öğrenim gören öğrencilerin fiziksel aktivite düzeyleri ile sağıklı yaşam biçimi davranışlarının belirlenmesi ve ilișkilendirilmesi. Int JSCS 2014; 1: 49-65.

14. Savcı S, Öztürk M, Arıkan H, İnal İnce D, Tokgözoğlu L. Physical activity levels of university students. Turk Kardiyol Dern Ars 2006; 34: 166-72.

15. Bakanlığı TCS. Obezite. Halk Sağlığı Genel Müdürlüğü (serial online). 2017 May (cited 2017 May 27). Available from: URL: http://beslenmehareket.saglik.gov. tr/

16. Erçim RE, Pekcan G. Genç yetişkinlerin beslenme durumunun sağıkkı yeme indeksi-2005 ile değerlendirilmesi. Besl Diyet Derg 2015; 42: 91-8.

17. Yurtseven E, Eren F, Vehid S, Koksal S, Ergin Oz E, Erdogan M. Beyaz yakalı calışanların beslenme alışkanlıklarının değerlendirilmesi. Kocatepe Tıp Derg 2014; 15: 20-6.

18. Demir Özdenk G. Bir üniversitenin çalışanlarının beslenme okuryazarlığı ve ilișkili etmenlerin incelenmesi (dissertation). Ankara: Hacettepe Univ. 2016.

19. Erdoğan M, Certel Z, Güvenç A. Masa bașı çalıșanlarda fiziksel aktivite düzeyi: Obezite ve diğer özelliklere göre incelenmesi (Akdeniz Üniversitesi Tıp Fakültesi Hastanesi Örneği). Spor Hekim Derg 2011; 46: 97-107.

20. Uyanık GE. Ofis çalışanlarında fiziksel aktivite düzeyinin yaşam kalitesine etkisi (dissertation). İstanbul: Beykent Univ. 2016.

21. Vural Ö, Eler S, Atalay Güzel N. Masa bașı çalışanlarda fiziksel aktivite düzeyi ve yaşam kalitesi ilişkisi. Spormetre beden eğitimi ve spor bilimleri dergisi 2010; 8: 69-75.

22. Bulut S. Bir fizik tedavi ve rehabilitasyon eğitim ve araștırma hastanesinde görev yapan personelin fiziksel aktivite düzeyi ve ilgili faktörlerin belirlenmesi (dissertation). Ankara: Hacettepe Univ. 2010.

23. Trost SG, Owen N, Bauman AE, Sallis JF, Brown W. Correlates of adults' participation in physical activity: review and update. Med Sci Sports Exerc 2002; 34: 1996-2001.

24. Yetim M. Sağlık çalışanlarının genel sağıı durumu, fiziksel aktivite düzeyleri ve etkileyen faktörler (dissertation). istanbul: Marmara Univ. 2017.

25. Deniz M. Yetişkinlerde fiziksel aktivite düzeyi ile sosyo-ekonomik durum arasındaki ilişkinin araştırılması (dissertation). Bursa: Uludağ Univ. 2011.

26. Satman I, Omer B, Tutuncu Y, Kalaca S, Gedik S, Dinccag N, et al. Twelveyear trends in the prevalence and risk factors of diabetes and prediabetes in Turkish adults. Eur J Epidemiol 2013; 28: 169-80.

27. Akova I. Yirmi yaș üstü erișkinlerde uyku süresi, kalitesi, fiziksel aktivite düzeyi ve bazı antropometrik ölçümler arasındaki ilişkiler (dissertation). Sivas: Cumhuriyet Univ.2016.

28. Erem C, Arslan C, Hacihasanoglu A, Deger O, Topbaş M, Ukinç K, et al. Prevalence of obesity and associated risk factors in a Turkish population (Trabzon city, Turkey). Obes Res 2004; 12: 1117-27.

29. Hatemi H, Yumuk VD, Turan N, Arik N. Prevalence of overweight and obesity in Turkey. Metab Syndr Relat Disord 2003; 1: 285-90.

30. Çayır A, Atak N, Köse S. Beslenme ve Diyet kliniğine basvuranlarda obezite sıklığı ve etkili faktörlerin belirlenmesi. Ankara Univ Tip Fak Mecm 2009; 64: 13-9.

31. Eriksen D, Rosthøj S, Burr H, Holtermann A. Sedentary work-Associations between five-year changes in occupational sitting time and body mass index. Prev Med 2015; 73: 1-5. 